\title{
The Economic and Social Benefits and the Barriers of Providing People with Disabilities Accessible Clean Water and Sanitation
}

\section{Jacqueline Noga ${ }^{1}$ and Gregor Wolbring ${ }^{2, *}$}

1 Faculty of Medicine, University of Calgary, 3330 Hospital Drive NW, Calgary, Alberta, T2N 4N1, Canada; E-Mail: jmnoga@ucalgary.ca

2 Faculty of Medicine, Department Community Health Sciences, Stream of Community Rehabilitation and Disability Studies, University of Calgary, 3330 Hospital Drive NW, Calgary, Alberta, T2N 4N1, Canada

* Author to whom correspondence should be addressed; E-Mail: gwolbrin@ucalgary.ca; Tel.:+1-403-210-7083; Fax: +1-403-220-6494.

Received: 11 September 2012; in revised form: 23 October 2012 / Accepted: 6 November 2012 / Published: 12 November 2012

\begin{abstract}
Resolution A/HRC/RES/16/2 adopted by the UN Human Rights Council on 8 April 2011 declared access to safe drinking water and sanitation a human right. However many people around the globe including people with disabilities do not have access to safe drinking water, hygiene or sanitation facilities. Inaccessibility of clean water sources, hygiene and sanitation facilities negatively impacts among others health, education, the ability to work, and the ability to partake in social activities. This paper looks at the benefits of, and access barriers to, clean water and sanitation for people with disabilities.
\end{abstract}

Keywords: accessibility; accessible infrastructure; clean water; benefit; disability; economic; sanitation

\section{Introduction}

Approximately 884 million people lack access to safe water sources and more than 2.6 billion people do not have access to sanitation (a system for the collection, transport, treatment and disposal or re-use of human excreta and associated hygiene [1]) [2]. Access to clean water and sanitation is also a major challenge faced by disabled people around the world [3] although concrete numbers do not exist. 
According to the Statement of the Committee on the Right to Sanitation (45th session, E/C.12/2010/1) of the United Nations Committee on Social, Economic and Cultural Right, "over a billion people still have no option but to practice open defecation"; no numbers have been generated for disabled people so far. The statement highlights further that "girls do not go to school in many parts of the world for lack of toilets, or lack of separate toilets for them" [1]. Access to toilets is also essential to disabled girls and boys [4,5] however no numbers exist as to extend of this problem. According to the 2004 United National General Assembly resolution 58/217, "water is critical for sustainable development, including environmental integrity and the eradication of poverty and hunger, and is indispensable for human health and well-being" [6]. Sustainable management of water resources is seen as vital for economic growth, public health, food security and stable societies [7]. Access, availability and affordability to water and sanitation, is seen as essential for sustainable development and poverty eradication [8]. According to the World Health Organization World Report on Disability and Rehabilitation, "Households with a disabled member are more likely to experience material hardship including food insecurity, poor housing, lack of access to safe water and sanitation, and inadequate access to health care" [9]. Furthermore, "people with disabilities have poorer health outcomes, lower education achievements, less economic participation and higher rates of poverty than people without disabilities" [9]. Cramped urban settings are often linked to decrease in water and sanitation access with over proportional negative impact on disabled people [10].

Access to Water, Sanitation and Hygiene (WASH) is a human right [11-13]. Various international instruments have affirmed the right to clean water or sanitation or both over time [14]. The right to clean water has been implicitly confirmed in the Protocol on Water and Health to the 1992 Convention on the Protection and Use of Transboundary Watercourses and International Lakes which came into force in 2005. Article 5 (1) of the Protocol states:

"Equitable access to water, adequate in terms both of quantity and of quality, should be provided for all members of the population, especially those who suffer a disadvantage or social exclusion" [15].

In 2002 the Committee on Economic, Social and Cultural Rights adopted the General Comment No. 15 on the right to water [16]. Water for Health was declared a Human right by the World Health Organization on 4 December 2002 [17]. According to the Statement of the Committee on the Right to Sanitation (45th session, E/C.12/2010/1) of the United Nations Committee on Social, Economic and Cultural Right, "States must ensure that everyone, without discrimination, has physical and affordable access to sanitation, in all spheres of life, which is safe, hygienic, secure, socially and culturally acceptable, provides privacy and ensures dignity" [1]. On 8 April 2011 the United Nation Human Rights Council passed resolution $\mathrm{A} / \mathrm{HRC} / \mathrm{RES} / 16 / 2$, The human right to safe drinking water and sanitation [2]. The resolution links the human right to safe drinking water and sanitation to the "right to an adequate standard of living and inextricably related to the right to the highest attainable standard of physical and mental health, as well as the right to life and human dignity" [2]. As to disabled people this resolution refers back to the Convention on the Rights of Persons with Disabilities as one of the justification for this resolution [2].

However many obstacles prevent access to clean water and to sanitation facilities for disabled people among others physical (distance to latrines or defecation areas, rough paths, narrow entrances 
and lack of space inside, steps to latrines, slippery floors, difficulty squatting — nothing to hold onto, need to put hands on latrine floor to balance), institutional (discriminatory legislation, policies/strategies that ignore disabled people, lack of consultation with disabled people, lack of information about accessible design options, lack of staff understanding, training, or experience on accessible designs, lack of mechanisms or forums for consultation with disabled people), economic (cost of constructions, user fees), and social/cultural (low status, harassment, negative traditional beliefs, pity, stigma, shame, overprotection, isolation, misinformation) [18].

An independent expert presented in 2010 a framework to the Human Rights Council "for assessing good practices (for providing clean water and sanitation) from a human rights perspective, using five normative criteria (availability, quality/safety, acceptability, accessibility and affordability) and five cross-cutting criteria (nondiscrimination, participation, accountability, impact and sustainability)" [19]. Our paper looks at some of the normative and cross cutting criteria outlined in the framework.

Economic arguments are one main consideration for global and local action; for example according to the Statement of the Committee on the Right to Sanitation (45th session, E/C.12/2010/1), "for every dollar invested in sanitation, there is about a nine-dollar long-term benefit in costs averted and productivity gained" [1]. Providing clean water and sanitation is suggested to have the potential to lead to increased employment and improvements in education and health [20]. We highlight in this commentary various benefits of providing access to clean water and sanitation for disabled people and the barriers to these benefits.

\section{Benefit}

\subsection{Education}

For children with disabilities, as for all children, "education is vital in itself, but also instrumental for participating in employment and other areas of social activity" [9]. Education is seen as a key to economic growth, lasting democracy, and greater stability and improved standards of living [21]. Various other benefits are reported [22-24]. Providing universally accessible water sources is seen to increase the opportunity to attend school and obtain a formal education [25]. UNICEF has as target 1, "to halve, by 2015, the proportion of people without sustainable access to safe drinking water and basic sanitation (MDG Target 10)" and as target 2 to "ensure that all schools have adequate child-friendly water and sanitation facilities, and hygiene education programme" [26]. Those living without proximal accessible water sources must commit their time to collecting water, thus in 1997 130 million children living in developing nations did not attend primary school as a result of the need to spend the time gathering water [27]. No numbers around this topic exist for disabled people. In 2001 WaterAid performed a study that looked at the impact of clean water and sanitation on education in Ethiopia, Ghana, India and Tanzania. It found that availability of clean water and sanitation increased school enrolment and reduced school absenteeism and drop-out rates [28]. Unfortunately this study did not highlight the effect on disabled students. WASH Guidelines for schools in low cost settings exist that cover disabled people [5]. However WASH actions that cover disabled people by themselves do not guarantee increase in education levels. The 2010 UNESCO report Education for all states. 
"In Burkina Faso, children reported as deaf or mute, living with a mental impairment or are blind were far less likely to be enrolled in school than those with a physical impairment. In 2006 , just $10 \%$ of deaf or mute 7- to 12-year-olds were in school.

"One qualitative study of attitudes towards children with autism in Ghana revealed they were widely described as 'useless and not capable of learning, (...) stubborn, lazy, or willfully disobedient" " [29]. "In a statement with wider application, the Ghanaian Ministry of Education, Sports and Science has powerfully captured the social prejudices that shape the education disadvantages associated with disability: The education of children with disabilities is undervalued by families, there is a lack of awareness about the potential of children with disabilities, children with disabilities in mainstream schools receive less attention from teachers and there is an overemphasis on academic achievement and examination as opposed to all round development of children" [29]. "In Malawi and the United Republic of Tanzania, having disabilities doubles the probability of children never having attended school, and in Burkina Faso it increases the risk of children being out of school by two and a half times" [29]. "In Bulgaria and Romania, net enrolment ratios for children aged 7 to 15 were over $90 \%$ in 2002 but only $58 \%$ for children with disabilities" [29]. "In Rwanda only 300 of an estimated 10,000 deaf children in the country were enrolled in primary and secondary schools, with another 9 in a private secondary school" [9]. In general as the report states, "Failure to address inequalities, stigmatization and discrimination linked to wealth, gender, ethnicity, language, location and disability is holding back progress towards Education for All" [29]. The level of education of disabled people is well below the equivalent numbers of non-disabled children in many countries. The UNESCO Education for all program generated a tool Deprivation and Marginalization in Education (DME) to highlight the situation of education for marginalized groups. However this new tool does not provide data in regards to disabled people.

\subsection{Economic Benefits Measured as GDP Lost or Gained}

According to the Statement of the Committee on the Right to Sanitation (45th session, E/C.12/2010/1), "for every dollar invested in sanitation, there is about a nine-dollar long-term benefit in costs averted and productivity gained" [1] (see also [30-33]). Water is also seen as an economic good [34,35]. GDP is seen to be lost due to inaccessible/unacceptable sanitation and clean water sources, and is experienced to some extent in almost every country in the world [36]. As to GDP lost as a result of poor sanitation one study looked the following countries: Benin, Burkina Faso, Central African Republic, Chad, Democratic Republic of Congo, The Republic of Congo, Ghana, Kenya, Liberia, Madagascar, Mauritania, Mozambique, Niger, Nigeria, Tanzania, Uganda, and Zambia. The following (Table 1) has been constructed from the different countries covered at [36]. 
Table 1. GDP lost as a result of poor sanitation in 17 African countries.

\begin{tabular}{lcc}
\hline Country & $\begin{array}{c}\text { Estimated \% of GDP lost } \\
\text { due to poor sanitation per } \\
\text { year }\end{array}$ & $\begin{array}{c}\text { Estimated US\$ lost due } \\
\text { to poor sanitation } \\
\text { per year }\end{array}$ \\
\hline Nigeria & 1.3 & 3 billion \\
Kenya & 0.9 & 324 million \\
Ghana & 1.6 & 290 million \\
Democratic Republic of Congo & 1.6 & 208 million \\
Tanzania & 1.0 & 206 million \\
Zambia & 1.3 & 194 million \\
Uganda & 1.1 & 177 million \\
Burkina Faso & 2.0 & 171 million \\
Chad & 2.1 & 156 million \\
Niger & 2.4 & 148 million \\
The Republic of Congo & 1.1 & 144 million \\
Mozambique & 1.2 & 124 million \\
Benin & 1.5 & 104 million \\
Madagascar & 1.0 & 103 million \\
Mauritania & 1.2 & 41 million \\
Central African Republic & 5.5 & 26 million \\
Liberia & 2.0 & 17.5 million \\
\hline
\end{tabular}

No studies exist that calculate GDP lost based on no access to clean water or sanitation for disabled people. Furthermore as with the area of education, any dynamics that are seen to increase GDP will not automatically include disabled people if water and sanitation is provided.

\subsubsection{Employment Benefits}

However numbers exist as to GDP lost due to unemployment of disabled people. Metts [37] estimated total GDP lost globally each year as a result of unemployed disabled people, measured in high, medium, and low income countries. High income countries lose between US\$891.28 billion and US\$1.26 trillion, medium income countries may lose from US\$338.55 billion up to US\$480.21 billion, and low income countries lose between US\$135.36 billion and US\$192.00 billion. Therefore, according to this study, the loss for developing nations is at maximum US\$192 billion annually, and for developed nations (assuming high income countries) is at maximum US\$1.26 trillion. In total, this amounts to between US\$1.37 and US\$1.94 trillion worldwide lost each year. A study by Buckup [38] covered the monetary losses experienced when people with disabilities are excluded from the work force. According to Buckup, there is economic justification for including people with disabilities in the work place, and there is economic evidence which shows the potential gains in GDP. The following table (Table 2) demonstrates the monetary losses associated with excluding people with disabilities from the workplace. 
Table 2. US\$ lost in 2001 as a result of excluding people with disabilities from the workplace [38].

\begin{tabular}{cc}
\hline Country & Dollars lost (US\$) \\
\hline Canada & 28.6 billion \\
South Africa & 17818 million \\
China & 11693 million \\
Thailand & 9576 million \\
Vietnam & 1821 million \\
Ethiopia & 667 million \\
Tanzania & 480 million \\
Zambia & 251 million \\
Namibia & 168 million \\
Malawi & 40 million \\
Zimbabwe & 20 million \\
\hline
\end{tabular}

Metts [37] and Buckup [38] show that the cost of people with disabilities not participating in the work force is substantial. Although there may be a portion of the population who are choosing not to participate, many studies have shown that most of the disabled population wants to work, but are unable [39].

Unemployment as well as non-participation in the labour market is common amongst people with disabilities, and chronic poverty is a serious concern [40]. Income support is significantly higher within the disabled population [41]. People with disabilities typically have lower incomes, if any income at all, which often results in poverty. The federal government is losing CAD\$10.4-13.1 billion each year as a result of poverty [42]. Individual poverty also impacts society via crime, low productivity, and intergenerational poverty [42]. Conversely, an increase in productivity which could be achieved by increasing the aggregate number of labourers would result in a substantial return to GDP; to be exact, CAD $\$ 1$ billion to CAD $\$ 1.5$ billion in Ontario [42]. The costs of unemployment are also extensive; Topel [43] and Moosa [44] researched the impact of unemployment on individual monetary loss, finding that unemployment results in increasing losses over time, both to the individual as wage is lost and to the economic market as output decreases. The costs associated with unemployment are inextricably linked to poverty; both the costs of unemployment and the costs of poverty have been researched using the cost of healthcare, crime, intergenerational poverty, lost productivity, and other social costs [42,45-47].

Empirical data is not readily available for developing nations, however it is known that these nations also experience economic burden as a result of unemployment and poverty [48,49]. Being able to work lessens poverty, and the ability to work can be attributed to accommodating environments and good health; thus, there are monetary gains experienced when people with disabilities are provided with accessible infrastructure.

\subsubsection{Income Benefits}

When universally accessible water sources are provided to a disabled individual, he/she is provided with a greater opportunity to attend school or participate in the labour market. There is a recognizable 
relationship between working and income and level of education and income in both developing and industrialized nations. In so called developed countries if ones individual level of education increases, income is likely to increase as well [50,51]. As to developing nations; Fields [52] produced a synthesis of studies which looked at the correlation between education and income in developing nations which showed that gains in income ranged from $3.6 \%$ to $17.2 \%$, with an average of $11.2 \%$ with each additional year of education. The same study found that the incidence of poverty was significantly higher (approximately 40\%) in households where the head of the house had only primary education or no education at all [52]. Boissiere [53] reported a positive relationship between education and income in developing countries within among other agricultural settings. It is not necessarily the case that a higher education guarantees a higher income, and how education plays itself out with income is context dependent especially around disabled people where being employed depends on many factors beside the level of education. Furthermore often work is done without remuneration such as in the case of household work or subsistence farming.

\subsection{Health}

Numerous studies highlight the health benefits of clean water and sanitation [31,54-61] although they do not normally cover the health status of disabled people. One stated that participatory methods linked to community based total-hygiene approaches are suitable "for encouraging the involvement of women, children, the elderly and people with disabilities who in some cultures may be reluctant or unable to express their views or unable to read and/or write" [62]. Furthermore various publications and report that cover water and sanitation such as the four editions of the United Nation World Water development report written under the leadership of UNESCO only cover disability with the meaning of disability adjusted life years and the increase in ill health in disability due to lack of clean water, sanitation and hygiene.

\section{Costs}

\subsection{The Cost of Clean Water}

The costs of providing clean water vary greatly depending on the treatment chosen. One study looked at different methods of sanitation for drinking water. Sobsey et al. looked at five different methods, namely Chlorination, Coagulation/Chlorination System, SODIS, a ceramic filter, and a biosand filter [63]. All were found to be effective in treating water, taking into account quantity, quality, ease of use, and cost when evaluating efficacy. Chlorine tablets cost from US\$0.01-0.001 for every litre of water, and the Coagulation/Chlorination System cost between US\$0.01-0.003 for every litre of water. The SODIS treatment costs as much as a bottle of water made from PET or PETE; the treatment simply requires that the water be placed in the sun in a plastic water bottle. A ceramic filter costs between US\$8-10 initially, and a filter replacement is US\$4 -5 , while a biosand filter costs from US\$25-100, but requires no further costs. It must be kept in mind that while the biosand filter and the SODIS method do not require any further follow up, while chlorine tablets, coagulation sachets, and ceramic filters must be kept in supply; this means some additional costs. In industrialized nations, clean water is mostly provided via piped sources; the annual cost would be 
between US\$9.6-US\$14.6 per capita for piped clean water. Providing clean water requires input costs which vary greatly depending in the treatment.

\subsection{The Cost of Sanitation}

The cost of providing accessible sanitation to communities/families varies greatly depending on geographical location, government subsidies, and type of infrastructure being built.

In industrialized nations, the costs of sanitation are most often discussed in terms of the costs of piped water, which range from US\$8.2 to US\$11.0 per capita annually [33]. Sanitation does not necessarily require clean water, and can be provided using simple infrastructure designs; the costs vary depending on the method used. The WHO world report on disability states, "In new construction, full compliance with all the requirements of accessibility standards is generally feasible at $1 \%$ of the total cost [9]. This number is based on three studies in America and cannot be applied to developing countries.

However according to Jones, the cost of producing a single block VIP latrine of 8 cubicles (urban), which included two access ramps, two widened doors, two support rails for 2 cubicles, and two raised toilet seats came to US\$8732.91, and was created for a school in Ethiopia in 2009 [64]. Jones states further that it costs less than $3 \%$ of the overall cost of a latrine to make a school latrine accessible in Ethiopia [64].

\section{The Situation}

\subsection{The Criterion of Accessibility}

So far globally, infrastructure design around clean water and sanitation is often still developed without the consideration of the needs of people with disabilities despite the existence of knowledge of what is needed in various settings from low to high income countries from urban to rural areas and in regards to various body ability differences [3,65-71]. The Sphere Handbook for example was developed by more than 400 organizations around the world involved in disaster response and set out the minimum standards in a disaster response. The Sphere project [72] in its 2011 update addressed disability as an issue cutting across all disaster response related areas such as water supply, sanitation, nutrition, food aid, shelter, and health services. Indeed in many cases the challenge is not lack of knowledge and guidelines but implementation [73]; for example in Canada we often see the wheelchair accessible label on restrooms which are not really accessible for wheelchair users. Furthermore even if they might be accessible to wheelchair users that does not mean they meet the needs of other disabled people such as blind people. Venter et al.'s 'Barriers to accessibility identified by needs analysis' [74] which demonstrate the reasons why people with disabilities are lacking access to basic needs.

\subsection{The Criterion of Affordability}

Between 40 and 90 per cent of disabled people around the world are living in poverty, unable to benefit from their socio-economic rights [75]. Disability is both a cause and consequence of poverty [76,77] and the dynamic differs between different places in the world [78]. In various places 
disabled people are categorized as the chronically hungry and God's Poor [79]. According to a former head of the World Bank, "Eliminating world poverty is unlikely to be achieved unless the rights and needs of disabled people are taken into account" [80]. At the same time disabled people are seen to not be enough involved in poverty reduction strategies in low [76] and high [81] income countries or development activities due to attitudinal, environmental and institutional barriers [82]. Furthermore as the report of the independent expert presented to the Human Rights Council [19] states, "In too many places, the poorest pay the most for water and sanitation services. Not being connected to the public network for water and sanitation services, people living in poverty sometimes have no other choice than to buy water from informal private vendors, who can charge 10 to 20 times more than public utilities" [19]. Some link privatization of water to unaffordability for the poor [83]. The report continues, "Sanitation and water facilities and services must be available for use at a price that is affordable to all people. The provision of services includes construction, maintenance of facilities, and treatment of water and disposal of faecal matter. Paying for these services must not limit people's capacity to acquire other basic goods and services guaranteed by human rights, such as food, housing, health services and education. Affordability does not necessarily require services to be provided free of charge. When people are unable, for reasons beyond their control, to gain access to sanitation or water through their own means, the State is obliged to find solutions for ensuring this access." [19].

The report also gives some examples as to how affordability could be ensured, "With respect to affordability, good practice examples might relate to, inter alia, the inclusion of sanitation and water services in social safety nets, microcredit programmes or revolving funds to help people afford the connection cost to the network, tariff structures with built-in cross-subsidies, policies regarding disconnections, or initiatives to monitor and regulate the price of water and sanitation" [19]. Question is what is the level of implementation of these solutions? Disabled people face for example various barriers in regards to accessing microcredit programs [82].

Between rich and poor areas, as well as urban and rural areas, there are vast differences in affordability, accessibility, and safety of the water. For example, in terms of wealth and demand for water, one study found that in developed nations water demand decreased as income decreased, and similarly in developing nations, water demand increased as income increased $[84,85]$. These different geographical and social environments may impact both the ability to use certain sources, and the demand for water supply in general. The differences within the disabled population and the experiences of people with disabilities within each of these groups requires further research to explicate the best method of providing clean water and sanitation.

As to developing countries various studies have generated data regarding the cost of providing accessible water sources in general (e.g., [33,86]). However most of the time as in the case of $[33,86]$ they do not look at the access cost in regards to disabled people. Studies that calculate the cost of making water and sanitation accessible for disabled people in developing countries are rare (for two cost covering documents see [64,87]). As to developed countries, the cost to adhere to accessibility guidelines developed in various countries are well known. Here the issue is more whether the guidelines are useful and to what extend they are adhered to. 


\subsection{The Criterion of Acceptability}

The report of the independent expert presented to the Human Rights Council [19] acknowledges that "perspectives differ with regard to which sanitation and water supply solutions are acceptable in a given context," and "personal sanitation is a highly sensitive issue across regions and cultures." It covers the need for privacy and separation of the sexes. What the report does not mention is the cultural bias toward disabled people that prevents them from using for example public washrooms; for example its reported that "because many in Bangladesh believe that impairments are contagious or a karmic punishment, disabled people are sometimes prevented from using public latrine facilities, which then forces them to use unsanitary practices [88].

\subsection{The Five Cross-Cutting Criteria (Nondiscrimination, Participation, Accountability, Impact and Sustainability)}

As to disabled people these cross-cutting criteria pose huge problems for various organizations involved in water and sanitation issues. To take the example of the 2012 United Nation World Water development report written under the leadership of UNESCO. The United Nations World Water Development Report 4 Volume 1 [89], Volume 2 [90] and Volume 3 [91] covered women $n=366$; indigenous $n=19$; poor $n=420$; poverty $n=234$; rural $n=247$; access $n=735$. The short term 'disab' that catches among others the terms 'disabled people' 'people with disability', 'people with disabilities' 'disability' and 'disabilities' showed up 8 times on 835 pages with every single incident linked to the concept 'disability adjusted life years'. The other three editions of the World Water development report had the same absence of coverage of disabled people. Given this reality the World Water development report is discriminatory, stifles the participation of disabled people by making them invisible, absolutely has now accountability to social groups such as disabled people, has a huge negative impact on disabled people, and has a very limited vision on what should be sustained. Many other existing water, sanitation and hygiene documents do not cover disabled people. As to accountability it is often questionable whether so called accessible water sources and sanitation facilities are really accessible for disabled people in high or low income countries. Furthermore as to accountability little knowledge exists as to the perception of the public towards the topic of water and sanitation and disabled people. Water and sanitation surveys normally do not cover disabled people. We just performed a review finding 289 surveys, none seeking the views and situation of disabled people. A comprehensive sustainable strategy around providing access to clean water, hygiene and sanitation for disabled people does not exist so far. Given the lack of data related to the reality of life of disabled people, what really works to improve their lives on ongoing bases especially in low income countries, and the spottiness of data related to impact on disabled people of access to water and sanitation the many attitudinal and other barriers disabled people face, generating a sustainable strategy faces many hurdles.

\section{Conclusion}

Access to WASH is a human right [11-13]. This article outlined that (a) providing people with disabilities with clean water and sanitation as part of the general design of water and sanitation 
infrastructures for the community produces a multitude of benefits (see Figure 1 below) but also faces various barriers; (b) that the economic benefits and other benefit outweigh economic cost attached to providing accessible clean water and sanitation and (c) that the case could be made stronger if more cost and benefit data in regards to access to water and sanitation for people with disabilities would be available; for a variety of measures one has to estimate from the data available for non-disabled people. The use of funding from international governmental organizations (IGOs) and NGOs can be beneficial; social funds from organizations such as the World Bank can be effective in providing the monetary requirements to implement interventions for people with disabilities [92].

However as this article highlighted the funding has to take into account local realities in general and of people with disabilities in particular. Policies and guidelines which currently do not recognize the water, hygiene and sanitation needs of people with disabilities can easily be revised to include them. However this is not enough. Attitudinal, visibility and other contextual barriers and the lack of data also have to be addressed in order to make the change a sustainable reality. We submit that there is an increasing effort to deal with the many of the problems outlined in this paper in order to increase access to water, hygiene and sanitation for people with disabilities.

The 2012 Report of the United Nations Special Rapporteur on the human right to safe drinking water and sanitation [13] recommended that the post-2015 development agenda should incorporate a stand-alone goal on water, sanitation and hygiene, to ensure that universal access to these services; closing the access gap existing between dominant groups and minority groups. The report states that future goals, targets and indicators on water, sanitation and hygiene must address among others individual-related inequalities (sex/gender, age, and disability) in the public and private spheres. It also recommends improvement in methodology such as monitoring of gender, age, and disability-related inequalities in public facilities such as schools and health facilities. The UNICEF-WHO Joint Monitoring Programme (JMP) working group highlighted that access to water and sanitation services is measured at the household level and that therefore household surveys and censuses currently do not allow generating numbers as to intra-household differences in access such as by sex, age, or disability [12]. They suggest adding a question to household surveys "to obtain information about the range and prevalence of barriers experienced by, inter alia, persons with disabilities, older persons, women and girls, and those with health-related mobility restrictions" [12].

However, what we still have to see is a widespread and long term application of the strategies and actions suggested with the active involvement of people with disabilities on local and global level. Our findings suggest that there is a need for much more qualitative and quantitative research to fill the data and knowledge gap in existence. More, best practices also have to be produced. We submit that our results suggest that research funding agencies should include access to water and sanitation for people with disabilities as a research priority. 
Figure 1. The conceptual link between including people with disabilities in drinking water and sanitation access policies and the social and economic benefits.

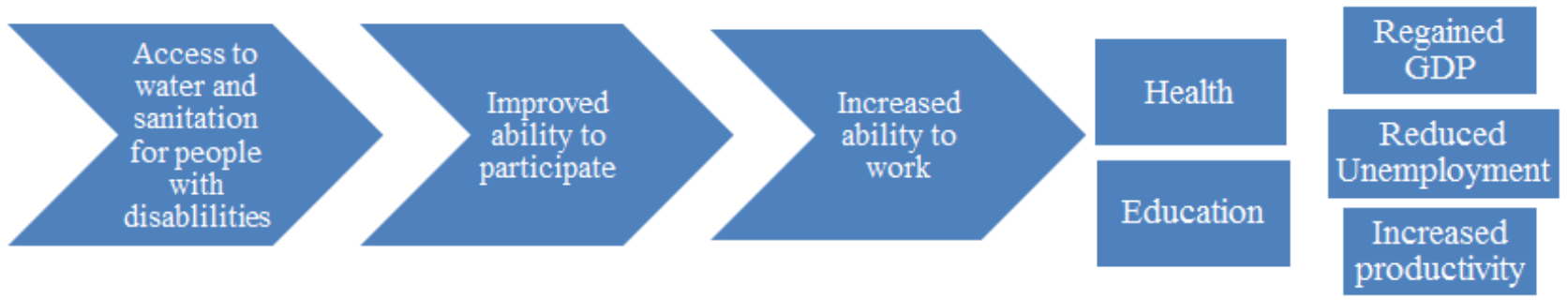

This Figure represents the general chain of events which may occur, resulting in the benefits which were discussed previously. The degree to which the benefits may occur is context dependent. For example, in developing nations, health may improve substantially, whereas the ability to work may still be hindered due to other issues. In comparison, it is possible that the health of a disabled individual in an industrialized nation is not in poor condition as a result of inaccessible water, but the individual is unemployed due to the inaccessibility in the workplace. Ideally, in a place where clean water and sanitation is not currently available, providing universally accessible water infrastructure will result in this chain of effects illustrated above.

\section{Acknowledgements}

We acknowledge the support of Daniel Dutton, Warren Noga, and the Wolb-Pack. The open access fee was paid through the open access fund of the University of Calgary.

\section{References}

1. United Nations Committee on Social, E.a.C.R. Statement of the Committee on the Right to Sanitation; 45th session, E/C.12/2010/1; United Nations: Geneva, Switzerland, 2010. Available online: http://www2.ohchr.org/english/bodies/cescr/docs/statements/E-C-12-20101.doc (accessed on 23 September 2012).

2. United Nations Human Rights Council. The Human Right to Safe Drinking Water and Sanitation: Resolution/Adopted by the Human Rights Council; A/HRC/RES/16/2; United Nations: Geneva, Switzerland, 8 April 2011. Available online: http://www.unhcr.org/refworld/docid/4dc1082 02.html (accessed on 23 September 2012).

3. Reed, B. Water Supply and Sanitation Access and Use by Physically Disabled People. DFID webpage. Available online: http://www.research4development.info/SearchResearch Database.asp?ProjectID=3872 (accessed on 23 September 2012).

4. UNICEF. Water, Sanitation and Hygiene (WASH) in Schools; UNICEF: New York, NY, USA, 2012. Available online: http://www.unicef.org/publications/files/CFS_WASH_E_web.pdf (accessed on 23 September 2012).

5. Adams, J.; Bartram, J.; Chartier, Y.; Sims, J. Water, Sanitation and Hygiene Standards for Schools in Low-Cost Settings; World Health Organization: Geneva, Switzerland, 2009. 
6. UNESCO. International Decade for Action, "Water for Life”, 2005-2015; UNESCO Resolution adopted by the General Assembly on the report of the Second Committee (A/58/485) 58/217; UNESCO: Paris, France, 2004. Available online: http://www.unesco.org/water/water_celebra tions/decades/water_for_life.pdf(accessed on 23 September 2012).

7. United Nations. United Nations Sustainable Management of Water Resources Vital to Achieving Anti-Poverty Goals Delegates Told as General Assembly High Level Dialogue Marks World Water Day; General Assembly GA/10925; United Nations: New York, NY, USA, 2010. Available online: http://www.un.org/News/Press/docs/2010/ga10925.doc.htm (accessed on 23 September 2012).

8. Mwanza, D. Water for Sustainable Development in Africa. In The World Summit on Sustainable Development; Springer: Dordrecht, The Netherlands, 2005; pp. 91-111.

9. WHO. World Health Organization World Report on Disability. WHO: Geneva, Switzerland, 2011. Available online: http://www.who.int/disabilities/world_report/2011/en/index.html (accessed on 23 September 2012).

10. WHO. Improving Equity in Health by Addressing Social Determinants; Lee, J.H., Sadana, R., Eds.; WHO: Geneva, Switzerland, 2011. Available online: whqlibdoc.who.int/ publications/2011/9789241503037_eng.pdf (accessed on 23 September 2012).

11. WaterAid. What the Global Report on Disability Means for the WASH Sector; WaterAid: London, UK, 2012. Available online: http://www.wateraid.org/documents/report_what the global_report_on_disability_means_for_the_wash_sector.pdf (accessed on 23 September 2012).

12. UNICEF-WHO. JMP Working Group on Equity and Non-Discrimination Final Report; WHO/UNICEF: Geneva, Switzerland, 2012. Available online: http://www.wssinfo.org/ fileadmin/user_upload/resources/JMP-END-WG-Final-Report-20120821.pdf (accessed on 23 September 2012).

13. de Albuquerque, C. Report of the Special Rapporteur on the Human Right to Safe Drinking Water and Sanitation; United Nations General Assembly: New York, NY, USA, 2012. Available online: http://daccess-dds-ny.un.org/doc/UNDOC/GEN/N12/456/53/PDF/N1245653.pdf?OpenElement (accessed on 23 September 2012).

14. Water Aid Freshwater Action Network. Freshwater Action Network Law on the Right to Water; WaterAid: London, UK, 2010. Available online: http://www.righttowater.info/code/Legislation _ 1.asp (accessed on 23 September 2012).

15. United Nations. Economic and Social Council Meeting of the Parties to the Convention on the Protection and Use of Transboundary Watercourses and International Law; United Nations: New York, NY, USA, 1999. Available online: http://www.unece.org/env/documents/2000/ wat/mp.wat.2000.1.e.pdf (accessed on 23 September 2012).

16. Committee on Economic, S.a.C.R. Substantive Issues Arising in the Implementation of the International Covenant on Economic, Social and Cultural Rights; General Comment No. 15; Committee on Economic, Social and Cultural Rights: New York, NY, USA, 2002. Available online: http://www2.ohchr.org/english/issues/water/docs/CESCR_GC_15.pdf (accessed on 23 September 2012). 
17. Aureli, A.; Brelet, C. Women and Water: An Ethical Issue; UNESCO: Paris, France, 2004. Available online: http://unesdoc.unesco.org/images/0013/001363/136357e.pdf (accessed on 23 September 2012).

18. WaterAid. Disability and Sanitation Soap and Toilets; Briefing Note 3; Water Aid: London, UK, 2012. Available online: http://www.wateraid.org/documents/plugin_documents/briefing _note_disability_and_sanitation_1.pdf (accessed on 23 September 2012).

19. de Albuquerque, C. Report of the Independent Expert on the Issue of Human Rights Obligations Related to Access to Safe Drinking Water and Sanitation; Addendum Progress report on the compilation of good practices; United Nations: New York, USA, 2010. Available online: http://www2.ohchr.org/english/bodies/hrcouncil/docs/15session/A.HRC.15.31.Add.1_en.pdf (accessed on 23 September 2012).

20. Jones, H.; Reed, B. Why should the Water and Sanitation Sector Consider Disabled People?; WELL briefing note 12; WELL, WEDC, Loughborough University: Loughborough; UK, 2005.

21. Dahlin, B.G. The Impact of Education on Economic Growth. Theory, Finding, and Policy Implications; Duke University: Durham, NC, USA, 2002.

22. Akhter, S. Indirect Benefits of Womens Education: Evidence from Bangladesh. PhD. Thesis, University of Wollongong, Wollongong, Australia, 2012. Available online: http://ro.uow.edu.au/theses/3576/ (accessed on 23 September 2012).

23. Kenayathulla, H.B. Cost benefit analysis in Malaysian education. Jurnal Internasional Manajemen Pendidikan 2012, 4, 1-18.

24. Riguer, M.G.L. Decent Work Status Report: The Philippines; Institute for Labour Studies: Manila, Philippines, 2008. Available online: http://www.nscb.gov.ph/ncs/10thNCS/papers /invited\%20papers/ips-22/ips22-01.pdf (accessed on 23 September 2012).

25. Bjorklund, G. Water Management in Developing Countries-Policy and Priorities for EU Development Cooperation; SIWI Report; Stockholm International Water Institute: Stockholm, Sweden, 2001. Available online:. http://www.orangesenqurak.org/UserFiles/File/SIWI/Report12_ Water\%20Management\%20in\%20Developing\%20Countries\%20SIWI\%20Recommendation\%20 for\%20EU\%20Development\%20Co-operation_2001.pdf (accessed on 23 September 2012).

26. UNICEF. UNICEF WASH Strategies, 2012. Available online: http://www.unicef.org/ wash/index_43084.html (accessed on 23 September 2012).

27. Edmonds, G. Wasted Time: The Price of Poor Access, 3 ed.; Technical Paper; ILO-International Labour Office: Geneva, Switzerland, 1998.

28. WaterAid. Water, Sanitation and Education; WaterAid: London, UK, 2001. Available online: http://www.wateraid.org/documents/water_san_and_education.pdf (accessed on 23 September 2012).

29. UNESCO. Education for All Global Monitoring Report 2010: Reaching the Marginalized; UNESCO: Paris, France, 2010. Available online: http://unesdoc.unesco.org/images/0018 1001866/186606E.pdf (accessed on 23 September 2012).

30. Hutton, G.; Haller, L. Evaluation of the Costs and Benefits of Water and Sanitation Improvements at the Global Level; World Health Organization: Geneva, Switzerland, 2004.

31. Haller, L.; Hutton, G.; Bartram, J. Estimating the costs and health benefits of water and sanitation improvements at global level. J. Water Health 2007, 5, 467. 
32. Hutton, G.; Haller, L.; Bartram, J. Global cost-benefit analysis of water supply and sanitation interventions. J. Water Health 2007, 5, 481-502.

33. Hutton, G.; Bartram, J. Global costs of attaining the millennium development goal for water supply and sanitation. Bull. World Health Organ. 2008, 86, 13-19.

34. Rogers, P.; Bhatia, R.; Huber, A. Water as a Social and Economic Good: How to Put the Principle into Practice; Global Water Partnership/Swedish International Development Cooperation Agency: Stockholm, Sweden, 1998.

35. Rogers, P.; De Silva, R.; Bhatia, R. Water is an economic good: How to use prices to promote equity, efficiency, and sustainability. Water Pol. 2002, 4, 1-17.

36. The Water and Sanitation Program (WSP) Africa: Economics of Sanitation Initiative. The Water and Sanitation Program (WSP), 2012. Available online: http://www.wsp.org/wsp/content/africaeconomic-impacts-sanitation (accessed on 23 September 2012).

37. Metts, R.L. Disability Issues, Trends and Recommendations for the World Bank (Full Text and Annexes); World Bank: Washington, DC, USA, 2000. Available online: http://siteresources.worldbank.org/DISABILITY/Resources/2806581172606907476/DisabilityIss uesMetts.pdf (accessed on 23 September 2012).

38. Buckup, S. The Price of Exclusion: The Economic Consequences of Excluding People with Disabilities from the World of Work; Employment Working Paper No. 43; International Labour Office: Geneva, Switzerland, 2009. Available online: http://www.ilo.org/wcmsp5/groups/ public/---ed_emp/---ifp_skills/documents/publication/wcms_119305.pdf (accessed on 23 September 2012).

39. Grech, S. Living with disability in rural Guatemala: Exploring connections and impacts on poverty. Int. J. Disabil. Community. Rehabil. 2008, 7.

40. Yeo, R. Chronic Poverty and Disability. Action on Disability and Development 2001; Chronic Poverty Research Centre: Somerset, UK. Available online: http:/www.chronicpoverty.org /uploads/publication_files/WP04_Yeo.pdf (accessed on 23 September 2012).

41. Mavromaras, K.; Oguzoglu, U.; Black, D.; Wilkins, R. Disability and Employment in the Australian Labour Market; Australian Government Department of Employment and Workplace Relations: Melbourne, Australia, 2007. Available online: http://www.safeworkaustralia.gov. $\mathrm{au} /$ sites/SWA/AboutSafeWorkAustralia/WhatWeDo/Publications/Documents/324/DisabilityAnd Employment_AustralianLabourMarket_2007_PDF.pdf (accessed on 23 September 2012).

42. Laurie, N. The Cost of Poverty: An Analysis of the Economic Cost of Poverty in Ontario; Ontario Association of Food Banks (OAFB): Toronto, Canada, 2008. Available online: http://www.oafb.ca/assets/pdfs/CostofPoverty.pdf (accessed on 23 September 2012).

43. Topel, R. Specific capital and unemployment: Measuring the costs and consequences of job loss. Carnegie-Rochester Conference Series on Public Policy 1990, 33, 181-214.

44. Moosa, I.A. On the costs of inflation and unemployment. Journal of Post Keynesian Economics 1997, 19, 651-666.

45. MacEwen, A.; Saulnier, C. The Cost of Poverty in Nova Scotia; Canadian Center for Policy Alternatives: Ottawa, Canada, 2010. Available online: http:/www.policyalternatives.ca/ publications/reports/?cost??poverty?-nova?scoti (accessed on 23 September 2012). 
46. Ivanova, I. The Cost of Povetry in BC; Summary; Canadian Center for Policy Alternatives: Ottawa, Canada, 2011. Available online: http://www.policyalternatives.ca/costofpovertybc (accessed on 23 September 2012).

47. Morris, A. The social cost of unemployment. Econ. Lab. Relat. Rev. 2002, 13, 207-225.

48. Te Velde, D.W.; Ackah, C.; Ajakaiye, O.; Aryeetey, E.; Bhattacharya, D.; Cali, M.; Fakiyesi, T.; Fulbert, A.G.; Jalilian, H.; Jemio, L.C. The Global Financial Crisis and Developing Countries; Overseas Development Institute (ODI): London, UK, 2009.

49. Naude, W. The financial crisis of 2008 and the developing countries; Discussion Paper No. 2009/01; United Nations University: Helsinki, Finland, 2009. Available online: http://www.wider .unu.edu/stc/repec/pdfs/rp2009/dp2009-01.pdf (accessed on 23 September 2012).

50. Day, J.; Newburger, E. The Big Payoff: Educational Attainment and Synthetic Estimates of Work-Life Earnings; Current Population Report; U.S. Department of Commerce: Washington, DC, USA, 2002; pp. 23-210.

51. Brenner, H. Explaining Aggregate Health Status (Mortality). Insights to the Possible Impact of the Economic Crisis Report to the European Commission; European Commission: Berlin, Germany, 2009. Available online: http://www.google.ca/url?sa=t\&rct=j\&q=explaining\%20aggre gate $\% 20$ health $\% 20$ status $\% 20$ (mortality). $\% 20$ insights $\% 20$ to $\% 20$ the $\% 20$ possible $\% 20$ impact $\% 20$ o $\mathrm{f} \% 20$ the $\% 20$ economic $\% 20$ crisis\&source $=$ web \&cd $=1 \&$ ved $=0$ CCgQFjAA\&url $=$ http $\% 3 \mathrm{~A} \% 2 \mathrm{~F} \% 2$ Fec.europa.eu\%2Fsocial\%2FBlobServlet\%3FdocId\%3D6644\%26langId\%3Den\&ei=ED5ZULT GE8HNiwKntYGIBw\&usg=AFQjCNGmcJ1HWCYXycD-wEDgUNgdnhwZ_g (accessed on 23 September 2012).

52. Fields, G. Education and Income Distribution in Developing Countries: A Review of the Literature; Cornell University: Ithaca, NY, USA, 1980. Available online: http://digitalcommons .ilr.cornell.edu/cgi/viewcontent.cgi?article $=1487 \&$ context $=$ articles\&sei-redir $=1 \&$ referer $=\mathrm{http} \% 3$ A $\% 2 F \% 2 F w w w . g o o g l e . c a \% 2 F u r l \% 3 F s a \% 3 D t \% 26 r c t \% 3 D j \% 26 q \% 3 D \% 2522$ education $\% 2520$ an d\%2520income\%2520distribution\%2520in\%2520developing\%2520countries\%2522\%26source\% 3Dweb\%26cd\%3D1\%26ved\%3D0CCMQFjAA\%26url\%3Dhttp\%253A\%252F\%252Fdigitalcom mons.ilr.cornell.edu\%252Fcgi\%252Fviewcontent.cgi\%253Farticle\%253D1487\%2526context\%2 53Darticles\%26ei\%3DkkFZUNeZC4zuigKv34CAAQ\%26usg\%3DAFQjCNGT7_jVtZXs1qK01I MI3P4YGHeWOw\#search=\%22education\%20income\%20distribution\%20developing\%20countr ies\%22 (accessed on 23September 2012).

53. Boissiere, M. Rationale for Public Investments in Primary Education in Developing Countries; World Bank, IEG: Washington, DC, USA, 2004. Available online: http://nweb90. worldbank.org/OED/oeddoclib.nsf/DocUNIDViewForJavaSearch/D62030543C676CBC85256F 1 500592961/\$file/education_public_investments_wp.pdf(accessed on 23 September 2012).

54. Rheingans, R.; Cumming, O.; Anderson, J.; Showalter, J. Estimating Inequities in Sanitation-Related Disease Burden and Estimating the Potential Impacts of Pro-Poor Targeting; Sustainable Sanitation and Water Management, London School of Hygiene \& Tropical Medicine: London, UK, 2012. Available online: http://www.sswm.info/sites/default/files/reference attachments/RHEINGANS\%202012\%20Estimating\%20Inequities\%20in\%20Sanitation\%20Relat ed\%20Disease\%20Burden.pdf (accessed on 23 September 2012). 
55. Harvey, P.A. Environmental sanitation crisis: More than just a health issue. Environ. Health Insights 2008, 2, 77.

56. Whittington, D.; Jeuland, M.; Barker, K.; Yuen, Y. Setting priorities, targeting subsidies among water, sanitation, and preventive health interventions in developing countries. World Dev. 2012, 40, 1546-1568.

57. Herbst, S.; Fayzieva, D.; Kistemann, T. Water and Sanitation-related Health aspects in Khorezm, Uzbekistan. In Cotton, Water, Salts and Soums; Springer: Berlin, Germany, 2012; pp. 141-153.

58. Esrey, S.A.; Potash, J.B.; Roberts, L.; Shiff, C. Effects of improved water supply and sanitation on ascariasis, diarrhoea, dracunculiasis, hookworm infection, schistosomiasis, and trachoma. Bull. World Health Organ. 1991, 69, 609.

59. Bartram, J.; Cairncross, S. Hygiene, sanitation, and water: Forgotten foundations of health. Plos Medicine 2010, 7, e1000367.

60. Fewtrell, L.; Kaufmann, R.B.; Kay, D.; Enanoria, W.; Haller, L.; Colford, J.M. Water, sanitation, and hygiene interventions to reduce diarrhoea in less developed countries: A systematic review and meta-analysis. Lancet Infect. Dis. 2005, 5, 42-52.

61. Frieden, T.R. A framework for public health action: The health impact pyramid. Am. J. Public Health 2010, 100, 590-595.

62. Peal, A.J. Hygiene Promotion in South Asia; Progress, Challenges and Emerging Issues; Water Supply and Sanitation Collaborative Council: Geneva, Switzerland, 2010. Available online: http://www.wsscc.org/sites/default/files/publications/15_peal_hygienepromotion_southasia_2010 .pdf (accessed on 23 September 2012).

63. Sobsey, M.D.; Stauber, C.E.; Casanova, L.M.; Brown, J.M.; Elliott, M.A. Point of use household drinking water filtration: A practical, effective solution for providing sustained access to safe drinking water in the developing world. Environ. Sci. Tech. 2008, 42, 4261-4267.

64. Jones, H. Inclusive Design of School Latrines-How Much Does it Cost and Who Benefits?; Water Supply and Sanitation Collaborative Council: Geneva Switzerland, 2011. Available online: http://www.wsscc.org/sites/default/files/publications/wedc_inclusive_design_of_school_latrines_ 2011.pdf (accessed on 23 September 2012).

65. McBeath, W.H. Health for all: A public health vision. Am. J. Public Health 1991, 81, 1560-1565.

66. Jones, H.; Parker, K.J.; Reed, R. Water Supply and Sanitation Access and Use by Physically Disabled People. A Literature Review; Water, Engineering and Development Centre, Loughborough University: Leicestershire, UK, 2002. Available online: http://wedc.lboro.ac.uk/ projects/proj_contents0/WEJY3\%20\%20WSS\%20Special\%20Needs/www/outputs/Literature $\% 2$ Oreview_watsan\%20for\%20disabled.pdf (accessed on 23 September 2012).

67. Jones, H.E.; Reed, R.A.; Bevan, J.E. Water and sanitation for the disabled in low-income countries. Proc. Inst. Civ. Eng. Municip. Eng. 2003, 156, 135-141.

68. Jones, H.; Reed, B. Water Supply and Sanitation Access and Use by Physically Disabled People. Report of Second Field-Work in Bangladesh; WEDC: Loughborough, UK, 2004. Available online: http://wedc.lboro.ac.uk/docs/research/WEJY3/Bangladesh_Report_2_Watsan_ for_disabled.pdf (accessed on 23 September 2012). 
69. Water Aid (Ethiopia). Briefing note. 9 Equal access for all-2 Water and sanitation access for people with motor disablities. WaterAid, 2006. Available online: http:/www.wateraid.org/ documents/plugin_documents/briefing_note_disability.pdf (accessed on 23 September 2012).

70. Danish International Development Agency (DANIDA). Access to water and sanitation for people with disabilities. DANIDA, 2010. Available online: http://www.danidadevforum.um.dk /en/menu/Topics/SocialDevelopment/WaterAndSanitation/ToolsAndReferences/GoodPractices/T echnicalIssueNotes/AccessToWaterAndSanitaionForPeopleWithDisabilities/ (accessed on 23 September 2012).

71. WaterAid. All people, one goal, all access. Water and sanitation access for people with disabilities Mali. Water Aid, 2010. Available online: http://www.wateraid.org/documents/ plugin_documents/all_people_one_goal_all_access.pdf (accessed on 23 September 2012).

72. The Sphere Project The Sphere Handbook: Humanitarian Charter and Minimum Standards in Humanitarian Response. The Sphere Project, 2012. Available online: http://www.spherehandbook.org/en/how-to-use-this-chapter-1/ (accessed on 23 September 2012).

73. Shah, S.A. Gender and building homes in disaster in Sindh, Pakistan. J. Gend. Dev. 2012, 20, 249-264.

74. Venter, C.J.; Bogopane, H.; Rickert, T.; Camba, J.; Venkatesh, A.; Mulikita, N.; Maunder, D.; Savill, T.; Stone, J. Improving Accessibility for People with Disabilities in Urban Areas; Cornell University: Ithaca, NY, USA 2002. Available online: http://digitalcommons.ilr.cornell.edu /cgi/viewcontent.cgi?article=1258\&context=gladnetcollect (accessed on 23 September 2012).

75. Elwan, A. Poverty and Disability: A Survey of the Literature; Discussion Paper Series, No. 9932:99; Social Protection Unit, Human Development Network, The World Bank: Washington, DC, USA, 1999.

76. Yeo, R.; Moore, K. Including disabled people in poverty reduction work. World Dev. 2003, 31, 571-590.

77. Mira, E.B. The social model analysis of disability and the majority world. Intersticios 2012, 6 , 279-288.

78. Beresford, P. Poverty and disabled people: Challenging dominant debates and policies. Disabil. Soc. 1996, 11, 553-567.

79. Hulme, D.; Shepherd, A. Conceptualizing chronic poverty. World Dev. 2003, 31, 403-423.

80. James D. Wolfensohn poor, disabled and shut out. Washington Post, 3 December 2002.

81. Buettgen, A.; Richardson, J.; Beckham, K.; Richardson, K.; Ward, M.; Riemer, M. We did it together: A participatory action research study on poverty and disability. Disabil. Soc. 2012, 27, 603-616.

82. Nuwagaba, E.L.; Nakabugo, M.; Tumukunde, M.; Ngirabakunzi, E.; Hartley, S.; Wade, A. Accessibility to micro-finance services by people with disabilities in Bushenyi District, Uganda. Disabil. Soc. 2012, 27, 175-190.

83. Grech, S. Recolonising debates or perpetuated coloniality? Decentring the spaces of disability, development and community in the global South. IJIE 2011, 15, 87-100.

84. Rosegrant, M.W.; Cai, X. Global water demand and supply projections. Water Int. 2002, 27, $170-182$. 
85. Cai, X.; Rosegrant, M.W. Global water demand and supply projections. Water Int. 2002, 27, 159-169.

86. Samra, S.; Crowley, J.; Fawzi, M.C.S. The right to water in rural Punjab: Assessing equitable access to water in the context of the ongoing Punjab rural water supply project. Health Hum. Right Int. J. 2011, 13, 1-14.

87. Handicap International. How to Build an Accessible Environment in Developing Countries; Manual \#2; Handicap International: Phnom Pemh, Cambodia, 2008. Available online: http://www.handicap-international.fr/fileadmin/documents/publications/Manual2-1_light.pdf (accessed on 23 September 2012).

88. World Bank. Social Analysis and Disability: A Guidance Note Incorporating Disability-Inclusive Development into Bank-Supported Projects. 2007. Available online: http://www.cndd.ca/assets/ research\%20documents/World\%20Bank/World\%20Bank_Social\%20Analysis\%20and\%20Disabi lity.pdf (accessed on 23 September 2012).

89. UNESCO. Managing Water Report under Uncertainty and Risk The United Nations World Water Development; Report 4; UNESCO: Paris, France, 2012; Volume 1. Available online: http://unesdoc.unesco.org/images/0021/002156/215644e.pdf (accessed on 23 September 2012).

90. UNESCO. Knowledge Report Base The United Nations World Water Development; Report 4; UNESCO: Paris, France, 2012; Volume 2. Available online: http://unesdoc.unesco.org/images/ 0021/002156/215644e.pdf\#page $=406$ (accessed on 23 September 2012).

91. UNESCO. Facing the Challenges The United Nations World Water Development; Report 4; UNESCO: Paris, France, 2012; Volume 3. Available online: http://unesdoc.unesco.org/images/ 0021/002156/215644e.pdf\#page=812 (accessed on 23 September 2012).

92. Dudzik, P.; McLeod, D. Including the Most Vulnerable: Social Funds and People with Disabilities; Report; Social Protection Unit, Human Development Network, The World Bank: Washington, DC, USA, 2000.

(C) 2012 by the authors; licensee MDPI, Basel, Switzerland. This article is an open access article distributed under the terms and conditions of the Creative Commons Attribution license (http://creativecommons.org/licenses/by/3.0/). 